\title{
Coastal management status of Banda Aceh city and Aceh Besar and the future trends
}

\author{
Muhammad Irham ${ }^{1,2,3, *}$, Muhammad Authar ${ }^{4}$, Edy Miswar ${ }^{3,5}$, Anwar Deli ${ }^{3,6}$ \\ ${ }^{1}$ Geographical Information Systems Laboratory, Faculty of Marine and Fisheries, Universitas Syiah Kuala \\ ${ }^{2}$ Marine and Fisheries Science Study Program, Universitas Syiah Kuala \\ ${ }^{3}$ Center for Environmental and Natural Resources Research (PPLH-SDA), Universitas Syiah Kuala \\ ${ }^{4}$ Program Studi Agribisnis, Fakultas Pertanian, Universitas Malikussaleh, Lhokseumawe, Indonesia \\ ${ }^{5}$ Center for Marine and Fisheries Research (PRKP), Universitas Syiah Kuala \\ ${ }^{6}$ Department of Agribusiness, Faculty of Agriculture, Universitas Syiah Kuala
}

\begin{abstract}
The study aims to identify how to manage coastal zones, the scope, rationality of coastal development, challenges, frameworks, environmental impacts, and future trends in Banda Aceh City and Aceh Besar. This research is based on information from the scientific literature and secondary data. The results of the study inform that currently integrated coastal management in Banda Aceh City and Aceh Besar is not mainly used for coastal development strategies. Therefore, this coastal area requires integrated management to build reciprocal interactions between coastal communities, policies, the environment to achieve sustainable development. This coastal zone has a diversity of natural resources, minerals and tourism potential and much more to explore, therefore Banda Aceh City and Aceh Besar need to take roles and initiatives in marine governance. Judging from the results of the trend that the status of coastal management in Banda Aceh City and Aceh Besar has development opportunities that can reduce coastal poverty and contribute to local economic development.
\end{abstract}

\section{Introduction}

The coastal zones of Banda Aceh City and Aceh Besar are geomorphologically and hydrologically dominated by the Krueng Aceh river system and the Malacca Strait in the north and the Indian Ocean in the west. Banda Ache City and Aceh Besar coastal zone (Figure 1) covers an area of $3,030 \mathrm{~km}^{2}$ or about $5 \%$ of the total area of Aceh Province. About $70 \%$ of the population lives in the coastal zone out of 695,536 residents [1]. The coastal zones of Banda Aceh City and Aceh Besar consist of 11 sub-districts that are directly adjacent to the sea and only 21 sub-districts that are not directly connected to the sea. Geographical features, the coastal zones of these two areas consist of two parts, namely the western zone and the northern zone [2]. The western region is known as the hilly coast consisting of rocky areas and sandy beaches. The northern region is a swamp and mangrove area, the most active accretion and erosion processes occurring in this area [3,4]. The estuary of Krueng Aceh river is located in this zone. The region is also covered by stable hilly areas and sandy beaches [5]. Many coastal residents are still poor, and vulnerable to natural disasters and anthropogenic hazards [6]. Climate change-driven events such as sea level rise, storm surges, coastal inundation, salinity intrusion and soil erosion are major natural disasters $[7,8,9]$.

The coast of Banda Aceh City and Aceh Besar are very dynamic and naturally always changing due to the interaction between land, sea, run off, and the atmosphere [10]. This interaction will be increasingly complex affecting the coastal environment as a result of weather changes such as storms and waves which are further exacerbated by sea level rise [11]. This vast coastal area requires holistic management and framework for sustainable development, conservation of coastal ecosystems and safety of coastal communities [12]. The coastal management and development program in this area has been going on for decades through a number of initiatives such as coastal embankment construction, coastal green belt development, and land reclamation, community-based management [13]. Therefore, this coastal area requires integrated holistic management.

Given the importance of the coastal conditions of Banda Aceh City and Aceh Besar holistically in order coastal planning management is more sustainable, it is necessary to look at the status of coastal management that has been carried out by the current government. Furthermore, in detail, it can be seen how the future trend of the management status in question is. Therefore, the purpose of this study is to identify how the management of coastal areas, scope, rationality of coastal development, challenges, frameworks, environmental impacts, and future trends in Aceh Besar and Banda Aceh City are identified.

Corresponding author: $\underline{\text { irham @unsyiah.ac.id }}$ 


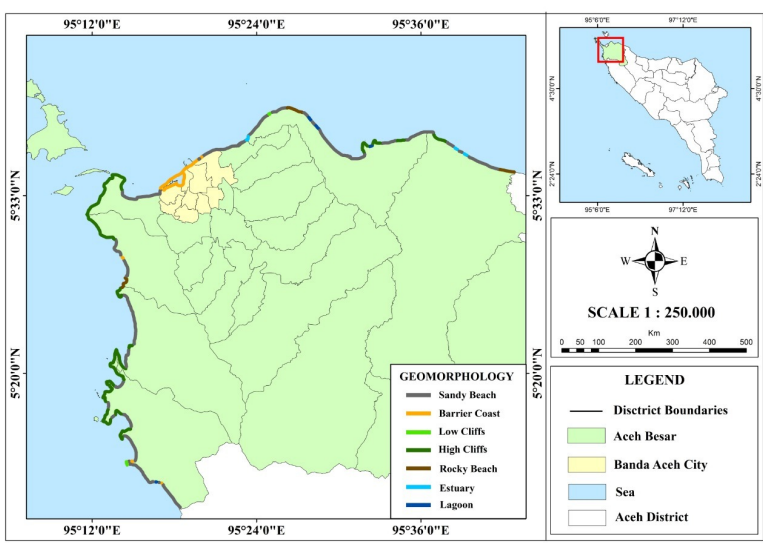

Fig. 1. Map of study area.

\section{Method}

This research is based on information from the scientific literature and secondary data. To collect secondary data, intensive literature review related to coastal demographic statistics, coastal development status, coastal management approaches, coastal resources, anthropogenic impacts related to coastal zones, coastal government surveys. In addition, several relevant government policy documents and reports were also collected from government agencies both online and offline.

Especially for management status, the method used is the Integrated Coastal Zone Management (ICZM) approach which is widely accepted as a means to achieve sustainable development in coastal areas. ICZM refers to a continuous and iterative dynamic process that includes a full cycle of information gathering, planning, decision making, management and implementation monitoring.

\section{Result and discussion}

\subsection{Coastal demographic}

The results of the study on the demographics of the Banda Aceh City and Aceh Besar residents can be seen in Table 1. The results show that the population of Banda Aceh City is growing at around $1.9 \%$ per year while for the Aceh Besar area, population growth is around $1.02 \%$ per year. Population growth in these two areas is almost the same but the number of immigrants continues to increase with an increasing trend of around $2-5 \%$ per year.

Table 1. The statistic of population and economic growth of Banca Aceh City and Aceh Besar.

\begin{tabular}{|l|l|r|r|r|r|r|r|}
\hline \multirow{2}{*}{\multicolumn{2}{|c|}{ Social }} & \multicolumn{3}{|c|}{ Banda Aceh City } & \multicolumn{3}{|c|}{ Aceh Besar } \\
\cline { 2 - 8 } & $\mathbf{2 0 1 7}$ & $\mathbf{2 0 1 8}$ & $\mathbf{2 0 1 9}$ & $\mathbf{2 0 1 7}$ & $\mathbf{2 0 1 8}$ & $\mathbf{2 0 1 9}$ \\
\hline 1 & Population & $2,581,000$ & 265,110 & 270,320 & 409,109 & 417,302 & 425,216 \\
\hline 2 & Population growth & 1.96 & 2.00 & 1.97 & 1.02 & 1.02 & 1.02 \\
\hline 3 & Poor people & 19,230 & 19,130 & 19,420 & 62,710 & 60,080 & 58,900 \\
\hline 4 & \% of poor people & 7.44 & 7.25 & 7.22 & 15.41 & 14.47 & 13.92 \\
\hline 5 & Human development index & 83.95 & 84.37 & 85.07 & 72.00 & 72.73 & 73.55 \\
\hline \multicolumn{2}{|c|}{ Economic } & & & & & & \\
\hline 1 & Gross Regional Domestic Bru & $16,685.21$ & $17,570.75$ & $18,617.56$ & $9,213.40$ & 9561.5 & 9977.7 \\
\hline 2 & Economic growth & 3.39 & 4.40 & 4.18 & 3.19 & 3.6 & 3.27 \\
\hline 3 & Per capita of GRDP (mil. Rp. & 62.94 & 65.52 & 67.38 & 28.23 & 29.52 & 30.12 \\
\hline
\end{tabular}

Source: BPS 2021 [1]
If we look at the economic growth in this area, it can be seen that economic growth is linear with population growth (Table 1). This indicates that the increase in the economy has triggered an increase in the urbanization population due to population mobility [14]. Migration is a complicated problem for every development of a coastal area because it is one of the factors in accelerating the rate of population growth in addition to the natural population growth factor.

Since the early 1980s, these two districts have experienced a demographic transition marked by a decrease in the death rate and birth rate as a consequence of increased welfare from economic development [15]. Apart from that, population growth also occurs due to urbanization and population mobility as a consequence of economic growth. Infrastructure development and implementation of programs that support coastal development are considered to have contributed significantly to the population growth of the study area. As a result of this population growth, the need for land for settlements, industry, infrastructure and services has also increased [16]. The use of limited resources by many people can result in exceeding the carrying capacity of the area. Therefore, the utilization of swamp, mangrove and coastal areas will have an impact on changing the landscape and trigger negative environmental impacts $[17,18]$. This impact will be broad and long term.

Coastal population growth, unfortunately, is not matched by good coastal zone management policies in the study area. This is indicated by the lack of policies to protect vulnerable and sensitive areas, the existence of several damaged ecosystem areas, the disappearance of some mangrove land cover and others [19]. Pollution handling policies, for example, which so far, some people still think that coastal areas are places for waste disposal, must be eliminated immediately [20, 21, 22]. The technology used in the management of coastal areas has not supported conducive conditions for coastal areas, both environmental management and handling of existing ecosystems and plants, especially mangroves.

\subsection{Coastal resources}

The results of the survey conducted there are four major groups of potential coastal resources in the study area, namely: (1) renewable resources, (2) non-renewable resources, (3) marine energy and (4) environmental services. The four groups are in the area of the most valuable resources both in terms of socio-economic importance and natural-cultural heritage. These resource areas include coastal transition areas, lagoons, embankments, salt marshes, mangrove forests, sea grass, coral reef, fisheries and marine offshore [23, 24].

The renewable resources consist of various types of fish, shrimp, seaweed, seagrass beds, mangroves, coral reefs including coastal aquaculture activities and marine culture. Non-recoverable resources include minerals, mining/excavation materials and hydrocarbon. Energy resources consist of OTEC (Ocean Thermal Energy Conservation), tides, waves and so on. Meanwhile, 
marine environmental services include tourism and sea transportation.

Table 2. Coastal community behavior in managing coastal resources.

\begin{tabular}{|c|c|c|c|}
\hline No & $\begin{array}{l}\text { Behavioral } \\
\text { Elements }\end{array}$ & $\begin{array}{c}\text { Coastal } \\
\text { community } \\
\text { behavior }\end{array}$ & $\begin{array}{l}\text { Expected } \\
\text { behavior }\end{array}$ \\
\hline 1. & Knowledge & $\begin{array}{l}\text { Lack of } \\
\text { understanding } \\
\text { of the potential } \\
\text { of Coastal } \\
\text { Resources that } \\
\text { can be utilized } \\
\text { The principle } \\
\text { that Coastal } \\
\text { Resources can } \\
\text { be exploited } \\
\text { continuously } \\
\text { without being } \\
\text { accompanied by } \\
\text { recovery } \\
\text { There is an } \\
\text { understanding } \\
\text { that activities on } \\
\text { land have no } \\
\text { effect on } \\
\text { Coastal } \\
\text { Resources }\end{array}$ & $\begin{array}{l}\text { - Understanding } \\
\text { the potential } \\
\text { of natural } \\
\text { resources and } \\
\text { access to their } \\
\text { optimal use } \\
\text { - The principle } \\
\text { that the } \\
\text { preservation } \\
\text { of Coastal } \\
\text { Resources } \\
\text { needs to be } \\
\text { maintained } \\
\text { - Knowing the } \\
\text { relationship } \\
\text { between } \\
\text { activities on } \\
\text { land and at sea }\end{array}$ \\
\hline 2. & $\begin{array}{l}\text { Response to } \\
\text { conservation }\end{array}$ & $\begin{array}{l}\text { - A priori to } \\
\text { coastal and } \\
\text { marine } \\
\text { damage } \\
\text { - Oriented to the } \\
\text { past and } \\
\text { difficult to } \\
\text { accept change } \\
\text { - Don't take } \\
\text { risks }\end{array}$ & $\begin{array}{l}\text { - Actively } \\
\text { seeking } \\
\text { breakthroughs } \\
\text { in } \\
\text { environmental } \\
\text { ly friendly } \\
\text { utilization } \\
\text { technologies } \\
\text { - Future } \\
\text { oriented and } \\
\text { open to change } \\
\text { - Perform } \\
\text { calculations } \\
\text { against risk } \\
\text { and } \\
\text { uncertainty }\end{array}$ \\
\hline 3. & $\begin{array}{ll}\text { Skills \& } \\
\text { Ability to } \\
\text { utilize } \\
\text { Resources }\end{array}$ & $\begin{array}{l}\text { - Too } \\
\text { dependent on } \\
\text { one type of } \\
\text { business due } \\
\text { to limited } \\
\text { skills } \\
\text { - Using fishing } \\
\text { gear without } \\
\text { caring about } \\
\text { the impact } \\
\text { - environment } \\
\text { Not able to } \\
\text { maintain the } \\
\text { condition of } \\
\text { Coastal } \\
\text { Resources } \\
\text { - There are } \\
\text { limitations in } \\
\text { processing } \\
\text { and marketing } \\
\text { the results }\end{array}$ & $\begin{array}{l}\text { - Implementing } \\
\text { business } \\
\text { diversification } \\
\text { - Using } \\
\text { environmental } \\
\text { ly friendly } \\
\text { response tools } \\
\text { (supporting } \\
\text { environmental } \\
\text { preservation) } \\
\text { - Carry out } \\
\text { conservation } \\
\text { efforts in the } \\
\text { coastal and } \\
\text { marine } \\
\text { environment } \\
\text { - Able to } \\
\text { process and } \\
\text { market the } \\
\text { results or } \\
\text { market } \\
\text { availability for } \\
\text { product } \\
\text { distribution }\end{array}$ \\
\hline
\end{tabular}

The utilization of resources that are not optimal until now, among others, because there are still obstacles, namely the average business scale is small below the economic scale, the quality of human resources is still low, the lack of mastery of technology and the level of utilization of resources is uneven and does not pay attention to the carrying capacity of the environment.

The results of the survey on community knowledge on coastal and marine resource management can be seen in Table 2. Table 2 shows that the behavior of coastal communities in understanding and managing marine and coastal resources is minimal and does not seem to understand the importance of marine and coastal resources for the future. This is marked by the nonoptimal use of the existing resources and the absence of the principle of sustainable use of existing resources.

\subsection{Anthropogenic impact related to coastal zones}

The massive impact of human intervention on the coast has resulted in water pollution. The results of the survey and analysis in the study area show that more than $80 \%$ of coastal pollution comes from land due to urban waste, the rest comes from marine transportation and marine discharge activities. As a result of this pollution, many marine habitats are polluted and die.

Another pressure experienced by coastal areas is land use (Table 3) and human populations (Table 1). The population growth of Banda Aceh and Aceh Besar, which averages $2.3 \%$ per year, has caused dependence on coastal land to increase [1]. Furthermore, human populations will indirectly depend on coastal and marine ecosystems, habitats and resources for food, building materials, building sites, agricultural and recreational areas. This limited capacity is also used as a waste disposal area, garbage and toxic materials. This pressure will continue to increase along with the increase in urbanization, transportation and industrialization due to increasing human demography and increasing use of coastal areas [25].

Table 3. Land land cover of Banda Aceh City and Aceh

\begin{tabular}{|l|r|r|r|r|r|r|}
\hline & \multicolumn{3}{|c|}{ Besar District. } \\
\hline Land Use/ Land & \multicolumn{3}{|c|}{ Banda Aceh } & \multicolumn{3}{c|}{ Aceh Besar } \\
\cline { 2 - 7 } \multicolumn{1}{c|}{ Cover } & $\mathbf{2 0 0 9}$ & $\mathbf{2 0 1 4}$ & $\mathbf{2 0 2 1}$ & $\mathbf{2 0 0 9}$ & $\mathbf{2 0 1 4}$ & $\mathbf{2 0 2 1}$ \\
\hline Bare Land & 16.4 & 15.3 & 14.2 & 1.8 & 1.6 & 1.4 \\
\hline Mangrove & 7.1 & 6.8 & 5.6 & 12.9 & 11.8 & 11.4 \\
\hline Settlement & 21.4 & 23.7 & 27.3 & 16.1 & 18.7 & 22.1 \\
\hline Agriculture & 22.3 & 21.1 & 19.5 & 56.3 & 54.3 & 50.8 \\
\hline Pond & 15.8 & 16.4 & 17.2 & 11.1 & 11.7 & 12.2 \\
\hline Water & 17 & 16.7 & 16.2 & 1.8 & 1.9 & 2.1 \\
\hline
\end{tabular}

Economic improvement in the study area also encourages industrial growth that will alter, disrupt and destroy coastal ecosystems, including sensitive habitats. The main industrial activities that affect coastal areas include port activities, fishery processing, ship building and other associated industries related to coastal and marine activities. Construction engineering activities often cause permanent habitat destruction or habitat degradation and fragmentation, due to land claims, 
coastal protection, extraction of basic materials, dumping and disposal [1].

\subsection{Coastal management approach}

The coastal area development policies that have been implemented so far are often partial and have a "topdown" pattern, so that they often do not reflect the interests and needs of the coastal area. Local communities, not having a "bottom-up" pattern, while in its implementation it does not utilize the existing potential optimally, including the values of local wisdom [24].

Community participation from the beginning in determining the problem will further ensure that the program to be implemented truly meets the needs of the local community. Such an approach also makes the community feel ownership and responsibility for the program so that it is easier to invite the community to participate in managing the resources they have. In turn, this approach method will increase public confidence and reduce community dependence on the government.

\subsection{Strategic issues}

As regions that share special autonomy, the cities of Banda Aceh and Aceh Besar have implemented a new paradigm of sustainable marine development [25, 26]. The existence of a new paradigm shows that several serious problems have become strategic issues in the management of coastal and marine resources in the cities of Banda Aceh and Aceh Besar. The results of the analysis show that there are five issues that need to be resolved immediately. The following is a description of the five issues based on the data [1].

The first issue is the condition of coastal and marine resources that are common property with quasi-open access. The existence of resources that are quasi-open access, then the actions of one party that harm the other party cannot be corrected by the market (market failure). This creates economic inefficiency because all parties will try to exploit resources as much as possible. This is the situation that is currently happening. Supported by financial resources and technology, parties who are stronger and able to exploit resources excessively will cause natural production resources to be disrupted. The degradation of the coastal and marine environment will be massive if this is not immediately anticipated. In the early 80's, many were surprised to see that development policies that only pursued economic growth and productivity had in fact caused serious damage to the environment. For example, the fisheries modernization program, which aims to increase the production of fishermen's catches using increasingly modern fishing technology, is not accompanied by socialization of a good understanding of the marine environment. This has a fatal impact on environmental sustainability because there is maximum exploitation of resources without regard to the existing sustainable potential.

The second issue is the degradation of the coastal and marine environment which poses a threat to the survival of coastal communities and fishermen such as pollution of the aquatic environment due to industrial and household waste. In addition to destroying the potential of aquatic resources, environmental degradation is also bad for the health and survival of fishermen, especially coastal communities. The degradation of the coastal and marine environment occurs due to several interrelated and very complex factors. Some experts state that this factor is more due to the level of education or human resources, poverty, facilities and infrastructure and government policies.

The third issue is poverty and social inequality. Poverty, social inequality, and the pressures of life do not allow family members to be actively involved in social responsibilities outside of the problems of life that are substantial for them. Such factors are often the reason for other parties to negatively assess the social behavior of coastal communities, especially fishing communities. Socio-economic changes in coastal villages or fishing villages have clarified the line of social stratification of the community. This perception only preserves the gap in social relations in political relations between the government and society.

The fourth issue is access to the use of limited technology. The increasing competition in the use of marine and coastal resources requires the community to maximize their production. One way that is used is the use of technology. The limited knowledge and ability in using this technology is one of the obstacles and triggers for the exploitation of resources that damage the sustainable potential and have a negative impact on the environment. One of them is the gap in the use of technology between large and traditional fishermen which results in the increasing urgency of traditional fishermen in competing for the use of marine resources.

The last issue is regulations and policies that are not conducive. Local governments can manage coastal and marine resources more rationally considering the availability of resources will determine the level of community prosperity. Marine and fisheries development policies that are implemented should not only pursue economic interests, but also be balanced proportionally with the commitment to preserve the existing marine fisheries resources. In addition, there must also be a high and consistent commitment in enforcing applicable legal regulations in order to avoid social and economic conflicts. Local wisdom must be accommodated as one of the legal institutions that can minimize conflicts between fishermen.

\subsection{Coastal management status}

The results of the study inform that currently integrated coastal management in Aceh Besar and Banda Aceh is mainly used for coastal development strategies. Therefore, this coastal area requires integrated management to build reciprocal interactions between coastal communities, policies, the environment to achieve sustainable development. Judging from the results of the trend that the status of coastal management in Aceh Besar and Banda Aceh has development opportunities that can reduce coastal poverty and contribute to local economic development. This coastal 
zone has a diversity of natural resources, minerals and tourism potential and much more to explore, therefore Aceh Besar and Banda Aceh need to take roles and initiatives in marine governance.

The coastal management approach relies on available information on various aspects of coastal ecosystems, processes, resources, natural hazards and their impacts, effective response by governments. Coastal zone management is very important for implementing sustainable development strategies in Aceh Besar and Banda Aceh City. The existence of linkages between the national level, sub-national level and local communities in each approach taken must be able to ensure sustainability both socio-economically and naturally.

\subsection{Future trends in coastal zone management}

Recently the management, development and planning of coastal areas in Banda Aceh and Aceh City must receive attention by the government. The ICZM approach should be seriously implemented which not only aims to help reduce the impact of disasters, but also provides opportunities for sustainable use of resources. ICZM will provide ecological environmental benefits which in turn will also provide survival strategies for millions of people who live at the mercy of nature. The Coastal Zone policy and strategy is an important step towards implementing ICZM. The results of the study conclude that there are several scopes and issues that need to be anticipated by policy holders as listed in Table 4 .

Table 4. Scope, work, challenges, opportunities and threats of ICZM in Banda Aceh City and Aceh Besar.

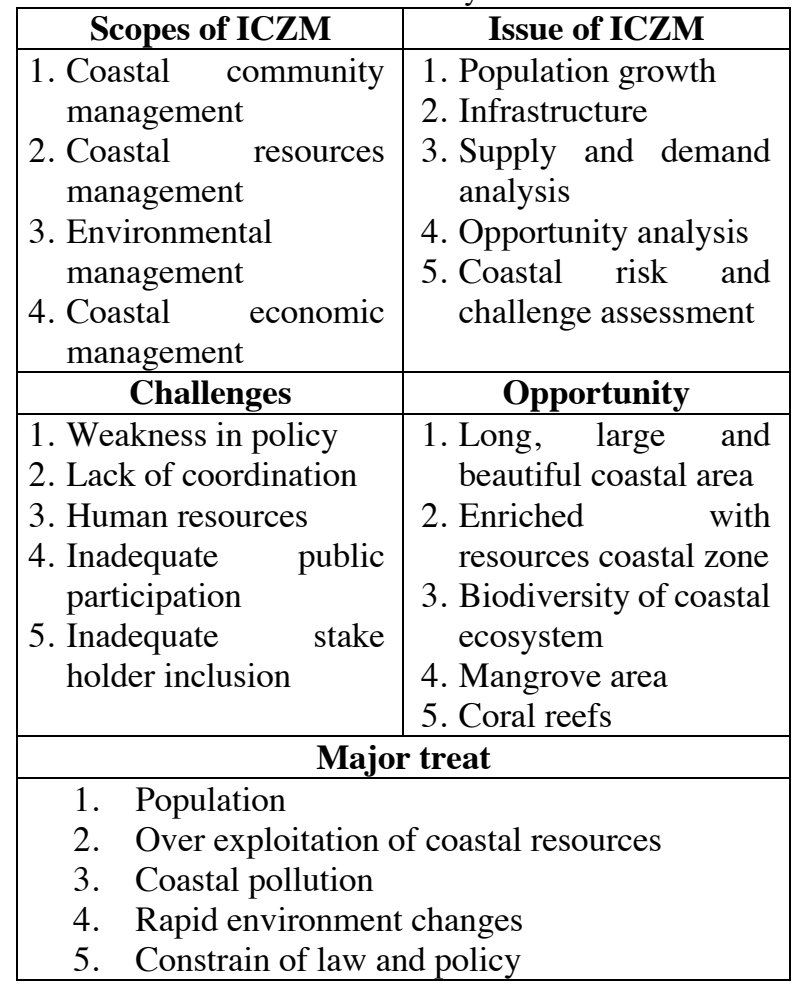

The coastal zone management policy (CZMP) in the study area covers a wide range of issues from economic development to ecosystem protection and conservation.
Unfortunately, there is no specific plan for dealing with natural disasters or reducing vulnerability. There are no clear guidelines on how local development agencies should work with government agencies. There are several reasons why this is happening due to: (1) noninclusion of professionals in Coastal Zone Management, (ii) unreasonable views of coastal zones, (iii) failure to create policies that are beneficial to coastal and marine areas.

\section{Conclusion}

Coastal zone management is very complex and multidimensional because it must address all socioeconomic and natural related problems. However, coastal zone management is very important on the coast of Aceh Besar and Banda Aceh City because almost $70 \%$ of the population lives in these areas. The analysis results of the status of coastal management are still lacking so that the sustainable development strategy in this area has not been able to guarantee the safety, security and sustainability of coastal communities.

Acknowledgment. The authors gratefully acknowledge Pusat Penelitian dan Pengabdian Kepada Masyarakat (LPPM) Universitas Syiah Kuala for their financial support.

\section{References}

1. BPS Provinsi Aceh. Provinsi Aceh dalam Angka (Aceh Province in Figures), Aceh (2021).

2. M. Irham, I. Rusydi, H. A. Haridhi, I. Setiawan, Y. Ilhamsyah, A. Deli, M. Rusdi, A. M. Siregar. J. Mar. Sci. Eng. 9, 8 (2021).

3. I. Adela, S. S. Nugraha, M. Irham, S. Syahreza. IOP Conf. Series: Earth and Environmental Science 273 (2019).

4. Rais, M. Irham, F. Adrian, A. Deli. IOP Conference Series: Materials Science and Engineering 1087 (2021).

5. E. Meilianda, C. M. Dohmen-Janssen, B. H. P. Maathuis, S. J. M. H. Hulscher, J. P. M. Mulderb. Marine Geology, 275, 1-4 (2008).

6. S. El-Masri, G. Tipple. International Planning Studies 7, 2 (2002).

7. M. R. Islam, N. A. Khan. Journal of the Asia Pacific Economy 23, 2 (2018).

8. M. Mousavi, Relationship Between Climate Change, Natural Disaster, and Resilience in Rural and Urban Societies, Handbook of Climate Change Resilience, 1 (2019)

9. W. J. W. Botzen, J. C. J. M. van Den Bergh. Environmental Hazard 8, 3 (2011).

10. M. Irham, R. Suri, I. Setiawan, A. Fuadi. IOP Conference Series: Earth and Environmental Science 674 (2021).

11. H. Ahmad. J. Coast. Zone Manag, 22 (2019).

12. Syamsidik, Tursina, A. Suppasri, M. Al'Ala, M. Luthfi. Nat. Hazards Earth Syst. Sci. 9, (2019).

13. J. Schmiedel, Environmental values and threats to coastal areas and the Baltic Green Belt. Coastline Reports. (2012). 
14. A. Marques, I. S. Martins, T. Kastner, C. Plutzar, M. C. Theurl, N. Eisenmenger, M. A. Huijbregts, R. Wood, K. Stadler, M. Bruckner, J. Canelas. Nature ecology \& evolution 3, 4 (2019).

15. Oxfam. Green Coast for Nature and People after the Tsunami, Dokumen anlisis kebijakan. (2007).

16. M. Rusdi, M. Irham, S. Sugianto, R. Roosli, MSS Ahamad, Y. Haditiar. Depik. 48, 1 (2021.

17. I. P. Sari, M. A. Sarong, M. Rusdi, A. Deli, M. Irham. IOP Conference Series: Earth and Environmental Science 674 (2021)

18. R. Azhar, M. Rusdi, M. Irham, A. Fuad. IOP Conference Series: Earth and Environmental Science 674 (2021).

19. Z. Nasution, M. T. D. Sunarno. J. Kebijakan Perikanan. Ind. 1, 1 (2009.

20. B. Neumann, A. T. Vafeidis, J. Zimmermann, R. J. Nicholls. PloS one 10, 3 (2015).

21. J. L. Merkens, D. Lincke, J. Hinkel, S. Brown, A. T. Vafeidis. Climatic Change 151, 3 (2018).

22. T. T. Jiang, J. F. Pan, X. M. Pu, B. Wang, J. J. Pan. Estuarine, Coastal and Shelf Science 164 (2015).

23. D. Dirhamsyah. Ocean \& coastal management. 49, 1-2 (2006).

24. E. M. Ferrer, C. M. Nozawa. Community-based coastal resources management in the Philippines: Key Concepts, Methods and Lessons Learned. (1997).

25. PEMDA Kota Banda Aceh. Rencana Pembangunan Jangka Menengah Daerah (RPJMD) Kota Banda Aceh, (2017).

26. PEMDA Aceh Besar. Rencana Pembangunan Jangka Menengah Daerah (RPJMD) Kabupaten Aceh Besar, (2017). 